\title{
Reflections on
}

\section{the governance \\ of urban land rent \\ in Italy today}

\author{
Stefano Stanghellini*
}

It is an established fact that in Italy the prolonged economic and financial crisis has depressed real estate values and therefore also that component of real estate value that is part of the price for the use of the land ${ }^{1}$. The judgment is almost universal, although there are some exceptions: Milan and its hinterland, some places of great landscape value, the historic centers of the "art cities", and little else.

On closer look, the reduction in purchase prices is the effect of the fall in demand, particularly strong in most of the country and especially for certain destinations. In relation to the negative demographic trend and the evolution of the economic system marked by activities and technologies requiring less space, the weakness of demand seems to be a structural condition for most Italian cities $^{2}$. This is not the case in other countries and cities around the world, even in Europe, so that doubts could be raised about the long-term validity of this statement. However today it seems that this condition is destined to persist for a long time. It is therefore with respect to it that we need to reflect and act.

The growth of Italian cities in the second half of the last century leaves those who deal with the city today with the immense task of working to regenerate and redevelop extensive areas subject to an initial urbanization and construction that has since become obsolete ${ }^{3}$.

\footnotetext{
${ }^{1}$ On this regard, see among others: Osservatorio del Mercato Immobiliare. Rapporto immobiliare 2018 (2018).

${ }^{2}$ Cfr. Istat (2018).

${ }^{3}$ For details, refer to Inu (2017).
}

keywords: rent, urban regeneration, redevelopment value, planning variant, promoter profit, principle of equity
Promoting urban redevelopment and regeneration, as is well known, is a much more complex business than promoting expansion. This is so for several reasons: the high starting price of the properties, the fragmentation of the real estate property, the occupation of part of the intervention properties by people or businesses, the costs of reclamation and demolition, the complicated procedures resulting from the fragmentation of public competences, and so on ${ }^{4}$.

Until 2008, that is, before the advent of the economic crisis, the difficulties mentioned above and the consequent higher intervention costs compared to building on vacant land, could be absorbed within the volume of the rent generated by the planning variants. If necessary, the volume of the rent thus created could be made larger through procedural simplifications and the contribution of public resources for the construction of works complementary to private investment ${ }^{5}$.

However, for some years now, the strategy just described has no longer been pursued due to the weakness of demand, the fall in purchase prices and the increased

\footnotetext{
${ }^{4}$ The difficulties faced by urban transformation, redevelopment and regeneration programs are the subject of an abundant literature. Among the numerous studies, due to the breadth of analysis and the continuing topicality, particular mention deserves Inu, Ministero dei Lavori Pubblici Di.Co.Ter. (2000).

${ }^{5}$ The functional methodologies for evaluating the projects to be defined in the context of a negotiation relationship between the public and private entities are presented and discussed, with reference to an extensive case study, in: Stanghellini S. (2012).
} 
entrepreneurial risk. It is therefore necessary to question whether there are alternative strategies.

The analysis of urban transformation and regeneration projects through the methodologies of the appraisal discipline is, in this regard, very useful. The models for estimating real estate values take into account the fact that in urban transformation processes rents are formed, as a result of the values that the properties subject to intervention acquire, and profits, with reference to entrepreneurial activity. As operational instruments of the economics, these models therefore provide to make explicit the monetary dimension that these quantities can reach $^{6}$.

It is known that rents and profits are conceptually different financial entities. Nevertheless they are interdependent in real estate development operations. In the estimation models that apply the "transformation value" criterion, after the probable selling prices have been deduced from the analysis of the real estate market and the probable costs from the analysis of the construction market, if the "profit" variable increases, the "rent" variable falls, and vice versa".

It is also known that the item relating to profits, in urban transformation projects, is a sort of black box, the content of which varies from time to time according to the project and the economic operator involved, even if the estimation theory is based on the "ordinary value", and therefore on an abstract identity of an economic operator characterized by the characteristics present more frequently in the reference market.

If it is believed that the urban redevelopment strategies given the impossibility or the inappropriateness of their entirely public realization - must be realized by private operators under market conditions, under the parity of construction costs, the field of analysis and of proposal is that - interposed between the level of revenues and that of costs - in which the rent and the profit interpenetrate. Hence, the indispensable condition for urban redevelopment to take place in a market context is that the operation gives rise to an adequate profit - that is, to a profit deemed sufficient by the promoter of the initiative in relation to other investment possibilities - and that for

\footnotetext{
${ }^{6}$ In Italy, among the first studies that investigated the structure and dynamics of costs and revenues in urban transformation projects, it is worth mentioning: Prizzon F. (2001). The feasibility assessments were more recently included in the body of the estimation discipline in: Roscelli R. (ed.) (2014).

7 In the urban appraisal literature, before the cost-revenue analysis approach or the analysis of discounted cash flows was established, for a long time the estimate of the value of the property to be transformed was at the center of the disciplinary interest through the so called "transformation value". Important references for following the disciplinary evolution from the estimate of the value of building areas to the estimate of the value of the real estate complexes to be transformed are: Forte C. (1968), Realfonzo A. (1994).
}

the properties subject to intervention, it achieves a value not lower than the entry price; in other words, urban redevelopment must lead to some increase in the rent incorporated in the price of the redeveloped properties.

The latter consideration recalls another one, related to the price with which the properties enter the urban transformation and regeneration projects. A significant critical point, in the context of the previous consideration, is given by the fact that the properties to be transformed or redeveloped are formally attributed, in the accounting of the entities and the proprietary companies, a book value that is inconsistent with current market indications and incompatible with the private investment. In other words, there are properties characterized by a high degree of obsolescence - physical, functional or positional - whose formal value conflicts with the real one. There is no doubt that the price of entry into urban transformation projects can only be the latter and that on this basis the project must be able to recreate the increase in rent mentioned above.

However, the recreated level of rent must be compatible with the principle of equity.

In this regard, with reference to the strategic scenario of urban regeneration, the author is convinced that the main tool for governing the transformation processes of the city in a fair way is local real estate taxation $(\mathrm{ICI}, \mathrm{IMU})^{8}$. If applied to a tax base close to market values, the tax rate commanded by the Municipality could give rise to virtuous, collaborative behavior in real estate properties. By bringing the rate towards the maximum level, increasing portions of rent would be drawn by the Municipality and therefore inert and uncooperative attitudes would be penalized, while a rate tending to zero would generate rent quotas where they are absent, and therefore would contribute to dilating the space between revenues and costs.

Unfortunately, the lack of reform of the cadastral valuations ${ }^{9}$, the political exploitation of local real estate taxation, the distrust of real estate property owners towards the commitments in principle declared by the Governments, the difficulty of the Municipalities in understanding and enhancing the synergies between urban planning and taxation, have impaired the appeal of this tool and - conversely - have provoked the revival of other tools, already tested in the past and then

\footnotetext{
${ }^{8}$ This position was fully expressed in: Stanghellini S. (1999b) following the analysis of the reform of the Land Registry set up in the second half of the 90 s which is reported in: Stanghellini S. (1999a).

9 After many years of development of appraisal models, simulations and programming by the Territory Agency first and then by the Revenue Agency, the draft law delegated that should have started the technical activities functional to the revision of the cadastral appraisals was not approved in the last legislature.
} 
abandoned, such as the contribution on the added value $^{10}$.

The challenge of urban regeneration therefore obliges the public decision-maker and the appraisal discipline, called to help the formation of the choices of the former, to think simultaneously on two different fronts according to the concrete operational situations:

- that of creating rent shares to be combined with profit in cities where the demand for real estate is weak;

-that of withdrawing and socializing significant portions of rent in cities where demand is strong and expectations of land development, as well as substantial profits, fuel the promotion of transformation projects.

As for local real estate taxation, it is known that the reform of cadastral valuations would require at least five years of time only for activities of a technical nature, to which the time of administrative procedures and political decisions should be added. Nonetheless, in the last legislature the government then in office decided to postpone the start of technical activities indefinitely.

Therefore, at the moment, having to make the best use of the available tools, it is evident that in cities where the real estate market is dynamic and prices are high, the contribution on the greater value generated by planning variants represents an important way to recover and socialize an important share of the urban land rent ${ }^{11}$. However, it is clear that the withdrawal must be accompanied by a reinvestment in public works aimed at rebalancing the qualitative gaps existing in cities between the more valuable and less valuable parts.

\footnotetext{
10 As it is known, the so-called Legislative Decree "Sblocca cantieri" n. 133/2014 amended art. 16, paragraph 4 of Presidential Decree 380/2001 introducing the letter d-ter) with which it is envisaged that, in the definition of the parametric tables, the urbanization costs are also determined in relation "to the evaluation of the greater value generated by interventions on areas or properties in urban planning variant, in derogation or with change of intended use. This higher value, calculated by the municipal administration, is divided not less than 50 percent between the municipality and the private part and paid by the latter to the municipality itself in the form of an extraordinary contribution [...] ". The contribution on the greater value, in the presence of cadastral estimates that do not reflect the actual real estate values, requires precise estimates with a controversial outcome, and therefore the emergence of problems similar to those that had led to the abandonment of the contributions for specific and generic improvements.

${ }^{11}$ Think, for example, of the extraordinary contribution provided for by the Rome Masterplan then endorsed at the national legislative level by art. 14, paragraph 16, letter f) of the Legislative Decree. n. 78/2010. "Roma Capitale" was entitled to provide for an "extraordinary contribution of up to 66 percent of the higher real estate value achievable, against significant real estate valuations generated by the general urban planning instrument, directly or indirectly, with respect to the previous regulations for public or general interest purposes, including urban redevelopment, environmental, building and social protection."
}

In urban areas with low demand, on the other hand, it is necessary to move more levers and ensure that, on the whole, they are able to create conditions of convenience for urban transformation and regeneration.

The rewards and urban compensations, represented by the attribution of additional building possibility to real estate properties, are a first lever, albeit very weakened compared to ten years ago. While the provision of bonuses and compensations aims to raise the real estate value that can be produced by the projects, the tax incentives for the energy efficiency of buildings have the effect of reducing actual costs. Similarly, the new energy efficiency is destined to reduce management costs. Public investments in the regeneration of public spaces, in turn, by improving urban quality produce positive externalities which contribute to raising the values of private real estate.

In short, by acting on the one hand on raising real estate values, on the other by reducing costs, the measures indicated, through a plurality of small contributions, can create conditions of private convenience for the regeneration and redevelopment intervention. The perspective is to create complementary relationships between measures that have different legislative origins and practical purposes, and therefore have been conceived independently of each other, making them synergistic for the purposes of urban regeneration.

Among the levers that can potentially be used to carry out the maneuver that has just been outlined, the reduction of urbanization costs is very popular in the action of regional and municipal administrations. In this case, the creation of a rent share is formed thanks to a corresponding reduction in intervention costs.

However, this widespread orientation cannot be shared. First, it is conceptually incorrect. By its very nature, urban regeneration requires that public space be well designed and built, as well as that it is well preserved and attractive. The reduction of urbanization costs is therefore conceptually wrong because it acts on a component of the private intervention costs whose presence is instead essential to give quality to the "public city". If the building quality of the renovated buildings is combined with streets and squares in a bad state of conservation, the goal of urban quality is not achieved, and the real estate value of the buildings suffers.

Secondly, the reduction of urbanization costs is a wrong financial maneuver. It is worth recalling that the private contribution to the construction of urbanization works was introduced in the urban planning system in the 1970 s to remedy the private construction of neighborhoods without essential public facilities, such as roads, car parks, underground utilities, social facilities, and so on. As a result of this, at the time the municipal administrations were forced to subsequently carry out, at the expense of the community, the public 
works that the private settlements lacked ${ }^{12}$. Today, by reducing the amount of urbanization charges, the same model is contradictorily being revived that in the 1950s and 1960s led to the construction of peripheries without quality.
${ }^{12}$ This profile of the development of Italian cities, in the context of the analysis of the processes of formation and private appropriation of absolute and differential urban rents, is exposed, among others, by: Campos Venuti G. (1967).

* Stefano Stanghellini, Department of Architecture and Arts, Università IUAV di Venezia

e-mail: stefano.stanghellini@iuav.it

\section{Bibliography}

Campos Venuti G., Amministrare l'urbanistica, Giulio Einaudi Editore, Torino, 1967.

FORTE C., Elementi di estimo urbano, Etas Kompass, Milano, 1968.

Inu, Ministero dei Lavori Pubblici Di.Co.Ter., Politiche urbane. Dai programmi alle politiche integrate di sviluppo urbano, a cura di Avarello P., Ricci M., INU Edizioni, Roma, 2000.

INU, Rapporto dal Territorio 2016, INU Edizioni, Roma, 2017. ISTAT, Rapporto annuale 2018. La situazione del Paese, Roma, 2018.

Osservatorio del Mercato Immobiliare, Rapporto immobiliare 2018. I/ settore residenziale, a cura dell'Ufficio Statistiche e Studi della Direzione Centrale Osservatorio Mercato Immobiliare e Servizi Estimativi dell'Agenzia delle Entrate con la collaborazione di ABI, Roma, 2018.

Osservatorio del Mercato Immobiliare, Rapporto immobiliare 2017. Immobili a destinazione terziaria, commerciale e produttiva, a cura della Divisione Servizi Direzione Centrale Servizi Estimativi e Osservatorio Mercato Immobi- liare dell'Agenzia delle Entrate con la collaborazione di Assilea, Roma, 2018.

PrIzzON F., Gli investimenti immobiliari. Analisi di mercato e valutazione economico-finanziaria degli interventi, Celid, Torino, 2001.

ReAlfonzo A., Teoria e metodo dell'estimo urbano, La Nuova Italia Scientifica, Roma, 1994.

RosCeluI R. (a cura di), Manuale di estimo. Valutazioni economiche ed esercizio della professione, Utet, Novara, 2014.

StanGhellini S., II nuovo Catasto dei Comuni. Le microzone e gli altri adempimenti previsti dal Dpr 138/98, Maggioli Editore, Rimini, 1999a.

STANGHeLLINI S., "Urbanistica, tributi e catasto: tre riforme complementari per il governo del territorio", in Curti F. (a cura di), Urbanistica e fiscalità locale. Orientamenti di riforma e buone pratiche in Italia e all'estero, Maggioli Editore, Rimini, 1999b.

StANGHeLLINI S., II negoziato pubblico privato nei progetti urbani. Principi, metodi e tecniche di valutazione, Dei Tipografia del Genio Civile, Roma, 2012. 


\section{Riflessioni sul governo della rendita fondiaria urbana oggi in Italia}

\author{
Stefano Stanghellini*
}

parole chiave: rendita, riqualificazione urbana,
variante urbanistica, valoredi trasformazione,
profitto del promotore, principio di equità
È un fatto acquisito che in Italia la prolungata crisi economica e finanziaria ha depresso i valori immobiliari e quindi anche la componente del valore immobiliare che compete al prezzo per l'uso del terreno ${ }^{1}$. Il giudizio è pressoché generalizzato, anche se esistono alcune eccezioni: Milano e il suo hinterland, alcuni luoghi di grande pregio paesaggistico, i centri storici delle città d'arte, e poco altro.

A ben vedere, la riduzione dei prezzi di compravendita è effetto della caduta della domanda, particolarmente forte in gran parte del Paese e soprattutto per determinate destinazioni. In relazione al trend demografico negativo e all'evoluzione del sistema economico contrassegnata da attività e tecnologie richiedenti spazi inferiori, la debolezza della domanda pare essere una condizione di tipo strutturale per gran parte delle città italiane ${ }^{2}$. Non è così in altri Paesi e città del mondo, anche europee, cosicché si potrebbero avanzare dubbi sulla validità di tale affermazione sul lungo periodo. Tuttavia oggi pare che l'odierna condizione sia destinata a permanere a lungo. È dunque rispetto ad essa che occorre riflettere ed agire.

La crescita delle città italiane compiutasi nella seconda metà dello scorso secolo lascia, a chi oggi si occupa della città, l'immane compito di adoperarsi per riqualificare estesi territori oggetto di una prima urbanizzazione ed edificazione che poi è divenuta obsoleta ${ }^{3}$.

La promozione della riqualificazione, come è noto, è una missione molto più complessa della promozione dell'espansione. Ciò per numerose ragioni: I'elevato prezzo di partenza degli immobili di intervento, la frammenta-

\footnotetext{
1 Si vedano al riguardo tra gli altri: Osservatorio del Mercato Immobiliare. Rapporto immobiliare 2018 (2018).

${ }^{2}$ Cfr. Istat (2018).

${ }^{3}$ Per elementi di dettaglio si rinvia a: Inu (2017).
}

zione della proprietà immobiliare, I'occupazione di parte degli immobili di intervento da parte di persone o di attività, i costi delle bonifiche e delle demolizioni, le complicate procedure derivanti dalla frammentazione delle competenze pubbliche, e via dicendo ${ }^{4}$.

Fino al 2008, cioè prima dell'avvento della crisi economica, le difficoltà sopra accennate ed i conseguenti maggiori costi di intervento rispetto all'edificazione su terreni liberi, potevano essere assorbiti all'interno del volume della rendita generato dalle varianti urbanistiche. In caso di necessità, il volume della rendita così creato poteva essere reso più capiente mediante semplificazioni procedurali e l'apporto di risorse pubbliche per la realizzazione di opere complementari all'investimento privato ${ }^{5}$.

Tuttavia da qualche anno la strategia immobiliare appena descritta non è più perseguibile a causa della debolezza della domanda, della caduta dei prezzi di compravendita e dell'accresciuto rischio imprenditoriale. Occorre quindi interrogarsi sulla disponibilità o meno di strategie sostitutive.

L'analisi dei progetti di trasformazione e riqualificazione urbana attraverso le metodologie proprie della disciplina estimativa risulta, a questo proposito, di grande utilità. I modelli di stima dei valori immobiliari tengono conto del fatto che nei processi di trasformazione urbana si formano rendite, per effetto dei valori che gli immobili oggetto di

\footnotetext{
${ }^{4}$ Le difficoltà in cui si imbattono i programmi di trasformazione, riqualificazione e rigenerazione urbana sono oggetto di una abbondante letteratura. Fra i numerosi studi, per l'ampiezza di analisi e la perdurante attualità merita una particolare segnalazione: Inu, Ministero dei Lavori Pubblici Di.Co.Ter.(2000).

${ }^{5}$ Le metodologie funzionali alla valutazione dei progetti da definire nell'ambito di un rapporto negoziale tra il soggetto pubblico e quello privato sono presentate e discusse, con riferimento ad una estesa casistica, in: Stanghellini S. (2012).
} 
intervento acquisiscono, e profitti, in riferimento all'attività imprenditoriale. In quanto strumenti operativi dell'economia, provvedono quindi ad esplicitare la dimensione monetaria che tali grandezze possono raggiungere ${ }^{6}$. È noto come le rendite e i profitti siano entità finanziarie concettualmente diverse. Ciò nondimeno esse sono interdipendenti nelle operazioni di sviluppo immobiliare. Nei modelli estimativi che applicano il criterio del "valore di trasformazione", dopo che dall'analisi del mercato immobiliare sono stati desunti i probabili prezzi di vendita e dall'analisi del mercato delle costruzioni i probabili costi, se la variabile "profitto" cresce, la variabile "rendita" cala, e viceversa ${ }^{7}$.

È altrettanto noto che la voce relativa ai profitti, nei progetti di trasformazione urbana, è una sorta di scatola nera, il cui contenuto varia di volta in volta a seconda del progetto e dell'operatore economico coinvolto, anche se la teoria estimativa poggia sull'"ordinarietà", e quindi si fonda sull'astratta identità di un operatore economico contraddistinto dalle caratteristiche presenti con maggiore frequenza nel mercato di riferimento.

Qualora si ritenga che le strategie di riqualificazione urbana - stante l'impossibilità o l'inopportunità di una loro realizzazione interamente pubblica - debbano essere realizzate da operatori privati in un contesto di mercato, a parità di costi di costruzione il campo di analisi e di proposta è quello - interposto tra il livello dei ricavi e quello dei costi - in cui la rendita e il profitto si compenetrano.

Ebbene, la condizione indispensabile perché la riqualificazione urbana si realizzi in un contesto di mercato è che l'operazione dia luogo ad un profitto adeguato - cioè ad un profitto ritenuto sufficiente dal promotore dell'iniziativa in rapporto ad altre possibilità di investimento - e che da essa per gli immobili oggetto di intervento consegua un valore non inferiore al prezzo di ingresso; in altri termini, occorre che la riqualificazione urbana porti ad un qualche incremento della rendita incorporata nel prezzo degli immobili di intervento.

Quest'ultima considerazione ne richiama un'altra, relativa al prezzo con cui gli immobili entrano nelle operazioni di trasformazione e riqualificazione urbana. Una rilevante criticità, nell'ambito della precedente considerazione, è data dalla circostanza che agli immobili da trasformare o

\footnotetext{
${ }^{6}$ In Italia fra i primi studi che hanno approfondito la struttura e la dinamica dei costi e dei ricavi nei progetti di trasformazione urbanistica merita citare: Prizzon F. (2001). Le valutazioni di fattibilità sono state più recentemente inserite nel corpo della disciplina estimativa in: Roscelli R. (a cura di) (2014).

${ }^{7}$ Nella letteratura di estimo urbano, prima che si affermasse l'approccio dell'analisi costi ricavi ovvero dell'analisi dei flussi di cassa scontati, al centro dell'interesse disciplinare è stata a lungo la stima del valore del bene immobile da trasformare attraverso il "valore di trasformazione". Riferimenti importanti per seguire l'evoluzione disciplinare avutasi dalla stima del valore delle aree edificabili alla stima del valore dei complessi immobiliari da trasformare sono: Forte C. (1968), Realfonzo A. (1994).
}

riqualificare è formalmente attribuito, nella contabilità degli enti e delle società proprietarie, un valore contabile non coerente con le attuali indicazioni di mercato e non compatibile con l'investimento privato. In altri termini, vi sono immobili connotati da un elevato grado di obsolescenza - fisica, funzionale o posizionale - il cui valore formale confligge con quello reale. Non v'è dubbio che il prezzo di ingresso nelle operazioni di trasformazione urbana non può essere che quest'ultimo e che su tale base il progetto deve potere ricreare l'incremento della rendita cui si accennava.

Il livello di rendita ricreato deve essere tuttavia compatibile con il principio dell'equità.

Al riguardo, con riferimento allo scenario strategico della riqualificazione urbana, è convinzione di chi scrive che il principale strumento per governare i processi di trasformazione della città in modo equo sia la fiscalità immobiliare locale $(\mathrm{ICl}, \mathrm{IMU})^{8}$. Se applicata ad una base imponibile prossima ai valori di mercato, I'aliquota fiscale governata dal Comune potrebbe dare luogo, nelle proprietà immobiliari, a comportamenti virtuosi, collaborativi. Portando l'aliquota verso il livello massimo si preleverebbero quote crescenti di rendita e quindi si penalizzerebbero gli atteggiamenti inerti e non collaborativi, mentre un'aliquota tendente allo zero generebbe quote di rendita laddove questa latita, e quindi concorrerebbe a dilatare lo spazio fra ricavi e costi.

Purtroppo la mancata riforma degli estimi catastali ${ }^{9}$, la strumentalizzazione politica della fiscalità immobiliare locale, la diffidenza della proprietà immobiliare verso gli impegni di principio dichiarati dai Governi, la difficoltà dei Comuni nel comprendere e valorizzare le sinergie tra pianificazione urbanistica e prelievo tributario, hanno menomato l'appeal di questo strumento e - di converso - provocato la riproposizione di altri strumenti, in passato già sperimentati e poi abbandonati, quali la contribuzione sul maggior valore ${ }^{10}$.

La sfida della rigenerazione urbana obbliga quindi il deci-

\footnotetext{
${ }^{8}$ Questa posizione era stata compiutamente espressa in: Stanghellini S. (1999b) a seguito dell'analisi della riforma del Catasto impostata nella seconda metà degli anni ' 90 di cui si dà conto in: Stanghellini S. (1999a).

${ }^{9}$ Dopo una pluriennale attività di messa a punto di modelli estimativi, di simulazioni e di programmazioni da parte dell'Agenzia del Territorio prima e dell'Agenzia delle Entrate poi, il Disegno di legge delega che avrebbe dovuto dare avvio alle attività tecniche funzionali alla revisione degli estimi catastali non è stato approvato nella scorsa legislatura.

${ }^{10}$ Come noto, il DL c.d. Sblocca cantieri n. 133/2014 ha modificato I'art. 16, comma 4 del Dpr 380/2001 introducendovi la lettera dter) con cui si è previsto che, nella definizione delle tabelle parametriche, gli oneri di urbanizzazione siano determinati anche in relazione "alla valutazione del maggior valore generato da interventi su aree o immobili in variante urbanistica, in deroga o con cambio di destinazione d'uso. Tale maggior valore, calcolato dall'amministrazione comunale, viene suddiviso in misura non
} 
sore pubblico e la disciplina estimativa, chiamata ad aiutare la formazione delle sue scelte, a ragionare contemporaneamente su due diversi fronti a seconda delle concrete situazioni operative:

- quello della creazione di quote di rendita da combinare con il profitto nelle città in cui la domanda del prodotto immobiliare è debole;

- quello del prelievo e della socializzazione di significative quote di rendita nelle città in cui la domanda è forte e le aspettative di valorizzazione fondiaria, oltre che di cospicui profitti, alimentano la promozione del progetti di trasformazione.

Quanto alla fiscalità immobiliare locale, è noto come la riforma degli estimi catastali richiederebbe almeno cinque anni di tempo solo per le attività di natura tecnica, ai quali dovrebbero aggiungersi i tempi delle procedure amministrative e delle decisioni politiche. Ciò nondimeno, nella scorsa legislatura il Governo allora in carica decise di rinviare l'inizio delle attività tecniche a tempo indeterminato.

Quindi, al momento, dovendosi utilizzare al meglio gli strumenti disponibili, è evidente che nelle città in cui il mercato immobiliare è dinamico ed i prezzi sono elevati, il contributo sul maggior valore generato dalle varianti urbanistiche rappresenta una importante modalità per recuperare e socializzare una quota importante della rendita fondiaria urbana ${ }^{11}$. È tuttavia evidente che il prelievo deve essere accompagnato da un reinvestimento in opere pubbliche volto a riequilibrare, nella città, i divari qualitativi esistenti fra le parti più pregiate e quelle meno.

Nelle aree urbane a debole domanda occorre invece muovere più leve e far sì che, nell'insieme, queste riescano ad originare condizioni di convenienza alla trasformazione e riqualificazione urbana.

Le premialità e le compensazioni urbanistiche, rappresentate dalla attribuzione alle proprietà immobiliari di quantità edificatorie, sono una prima leva, seppur molto depotenziata rispetto ad una decina di anni fa. Mentre la pre-

inferiore al 50 per cento tra il comune e la parte privata e da quest'ultima versato al comune stesso sotto forma di contributo straordinario [...]". Il contributo sul maggior valore, in presenza di estimi catastali che non riflettono gli effettivi valori immobiliari, richiede stime di carattere puntuale di controverso esito, e quindi l'insorgere di problematiche analoghe a quelle che avevano determinato l'abbandono dei contributi di miglioria specifica e generica.

${ }^{11} \mathrm{Si}$ pensi, ad esempio, al contributo straordinario previsto dal Piano Regolatore di Roma poi avallato a livello legislativo nazionale dall'art. 14, comma 16, lettera f) del D.L. n. 78/2010. Roma Capitale è stata legittimata a prevedere un "contributo straordinario nella misura massima del 66 per cento del maggior valore immobiliare conseguibile, a fronte di rilevanti valorizzazioni immobiliari generate dallo strumento urbanistico generale, in via diretta o indiretta, rispetto alla disciplina previgente per la realizzazione di finalità pubbliche o di interesse generale, ivi comprese quelle di riqualificazione urbana, di tutela ambientale, edilizia e sociale." visione di premialità e di compensazioni mira ad elevare il valore immobiliare producibile dal progetto, gli incentivi fiscali per l'efficientamento energetico degli edifici hanno l'effetto di ridurre i costi effettivi. Analogamente, il sopraggiunto efficientamento energetico è destinato a ridurre $i$ costi di gestione. Gli investimenti pubblici nella riqualificazione degli spazi pubblici, a loro volta, migliorando la qualità urbana producono esternalità positive che concorrono ad innalzare i valori dei beni immobili privati.

Insomma, per un verso agendo sull'innalzamento dei valori immobiliari, per l'altro sulla riduzione dei costi, le misure segnalate, attraverso una pluralità di piccoli apporti, possono creare condizioni di convenienza privata all'intervento di riqualificazione. La prospettiva è quella di creare rapporti di complementarietà tra misure che hanno diversa origine legislativa e finalità pratica, e quindi sono state concepite autonomamente l'una dall'altra, rendendole sinergiche ai fini della riqualificazione urbana.

Fra le leve potenzialmente utilizzabili per realizzare la manovra che è stata appena delineata, nell'azione delle amministrazioni regionali e comunali gode di grande popolarità la riduzione degli oneri di urbanizzazione. In questo caso, la creazione di una quota di rendita si forma grazie ad una corrispondente riduzione dei costi di intervento.

Questo diffuso orientamento non è tuttavia condivisibile. In primo luogo, esso è concettualmente errato. Per sua stessa natura la riqualificazione urbana richiede che lo spazio pubblico sia ben progettato e realizzato, ed anche che sia ben conservato e che risulti attraente. La riduzione degli oneri urbanizzativi è dunque concettualmente errata perché agisce su una componente dei costi privati di intervento la cui presenza è invece essenziale per conferire qualità alla "città pubblica". Se la qualità edilizia degli edifici rinnovati si abbina a strade e piazze in cattivo stato di conservazione, l'obiettivo della qualità urbana non si raggiunge ed il valore immobiliare degli edifici ne soffre. In secondo luogo, la riduzione degli oneri di urbanizzazione è una manovra finanziaria errata. Merita richiamare che la contribuzione privata alla realizzazione delle opere di urbanizzazione è stata introdotta nell'ordinamento urbanistico negli anni ' 70 per porre rimedio alla realizzazione privata di quartieri privi di dotazioni pubbliche essenziali, quali le strade, i parcheggi, i sottoservizi, le attrezzature sociali, e via dicendo. Per effetto di ciò, all'epoca le Amministrazioni comunali erano costrette a realizzare successivamente, a spese della collettività, le opere pubbliche di cui erano privi gli insediamenti privati ${ }^{12}$. Oggi, riducendo l'importo degli oneri di urbanizzazione si fa contraddittoriamente rivivere, nella città che si vorrebbe riqualificare, il medesimo modello che negli anni '50 e '60 ha portato alla edificazione di periferie senza qualità.

\footnotetext{
${ }^{12}$ Questo profilo dello sviluppo delle città italiane, nell'ambito dell'analisi dei processi di formazione ed appropriazione privata delle rendite urbane assolute e differenziali, è messo a nudo, fra gli altri, da: Campos Venuti G. (1967).
} 
* Stefano Stanghellini, Dipartimento di Culture del Progetto, Università IUAV di Venezia

e-mail: stefano.stanghellini@iuav.it

\section{Bibliografia}

Campos Venuti G., Amministrare l'urbanistica, Giulio Einaudi Editore, Torino, 1967.

FORTE C., Elementi di estimo urbano, Etas Kompass, Milano, 1968.

Inu, Ministero dei Lavori Pubblici Di.Co.Ter., Politiche urbane. Dai programmi alle politiche integrate di sviluppo urbano, a cura di Avarello P., Ricci M., INU Edizioni, Roma, 2000.

INU, Rapporto dal Territorio 2016, INU Edizioni, Roma, 2017. Istat, Rapporto annuale 2018. La situazione del Paese, Roma, 2018.

Osservatorio del Mercato Immobiliare, Rapporto immobiliare 2018. II settore residenziale, a cura dell'Ufficio Statistiche e Studi della Direzione Centrale Osservatorio Mercato Immobiliare e Servizi Estimativi dell'Agenzia delle Entrate con la collaborazione di ABI, Roma, 2018.

Osservatorio del Mercato Immobiliare, Rapporto immobiliare 2017. Immobili a destinazione terziaria, commerciale e produttiva, a cura della Divisione Servizi Direzione Centrale Servizi Estimativi e Osservatorio Mercato Immobi- liare dell'Agenzia delle Entrate con la collaborazione di Assilea, Roma, 2018.

Prizzon F., Gli investimenti immobiliari. Analisi di mercato e valutazione economico-finanziaria degli interventi, Celid, Torino, 2001.

Realfonzo A., Teoria e metodo dell'estimo urbano, La Nuova Italia Scientifica, Roma, 1994.

Roscelti R. (a cura di), Manuale di estimo. Valutazioni economiche ed esercizio della professione, Utet, Novara, 2014.

Stanghellini S., II nuovo Catasto dei Comuni. Le microzone e gli altri adempimenti previsti dal Dpr 138/98, Maggioli Editore, Rimini, 1999a.

StANGHelliNI S., "Urbanistica, tributi e catasto: tre riforme complementari per il governo del territorio", in Curti F. (a cura di), Urbanistica e fiscalità locale. Orientamenti di riforma e buone pratiche in Italia e all'estero, Maggioli Editore, Rimini, 1999b.

StANGHeLlini S., I/ negoziato pubblico privato nei progetti urbani. Principi, metodi e tecniche di valutazione, Dei Tipografia del Genio Civile, Roma, 2012. 